\title{
The Americanization of Scott County, 1914-1918*
}

\author{
STEVEN WRede
}

WHEN THE United States entered World War I, the attitude of the American public toward citizens of German descent changed from positive to negative quite abruptly. GermanAmericans generally had been respected by their fellow citizens, but when Germany became identified as the enemy, their loyalty to the stars and stripes was questioned. Certain measures to assure the loyalty of German-Americans were carried out. The Committee on Public Information of the United States government helped organize the Friends of German Democracy, a group that attempted to arouse patriotism among German-Americans. In October, 1917, Congress passed the Espionage Act, which forced all foreign language newspapers to take a pro-American stand or cease publication. A Department of Interior conference on Americanization studied the use of the German language in American schools, homes and factories, and recommended the teaching of English to German-Americans. In several states, including Iowa, government forbade the use of any foreign language in public. German aliens living in the United States were required to register as such and were

*Funding for the research on this article was made possible through the Iowa State University Alumni Association. 
placed under various work and travel restrictions. Angry mobs of patriotic citizens occasionally went beyond legal means to ensure loyalty and often coerced German-Americans into public flag-kissing and pledge-of-allegiance ceremonies. ${ }^{1}$

Coercive and sometimes shameful activities of this nature occurred in lowa during the war. They were especially prevalent in Scott County. From the 1840s on, large numbers of Germans had settled in Scott County, and at the time of World War I between one-quarter and one-third of the county's 250,000 residents were of German descent. ${ }^{2}$ There were numerous GermanAmerican organizations in the county, including one of the most important chapters of the Turn-Geminde in the Midwest, the largest bank in the state, and two German-language newspapers. German-Americans held prominent positions, owning some of the largest business establishments and farms in the area. Between 1890 and World War I, four German-Americans had been elected mayor of Davenport. With such a large and influential German-American population in Scott County, the events and emotions surrounding the war naturally had a strong effect.

An overall suspicious attitude toward Scott County GermanAmericans is reflected in consistent prejudical reporting by local newspapers. On July 19, 1918, the Davenport Democrat and

\footnotetext{
${ }^{1}$ For an excellent discussion of the general effects of the war on those of foreign birth or with strong ties to their European homelands readers are advised to consult John Higham's Strangers in the Land: Patterns of Nativism 18601925 (New Brunswick: Rutgers University Press, 1955), and H. C. Peterson and Gilbert Fite's Opponents of War (Seattle: University of Washington Press, 1957). A good description of the U.S. government's efforts to gain the support of the foreign-born is found in James Mock and Cerdic Larson's Words that Won the War: The Story of the Committee on Public Information, 1917-1919 (Princeton: Princeton University Press, 1939). The most complete study on the effects of the war on German-Americans, especially in the Midwest, is Carl Wittke's German-Americans and the World War (Columbus, Ohio Archaelogical and Historical Society, 1936).

${ }^{2}$ Estimate based on information found in Census of Iowa for the Year 1915 (Des Moines: Executive Council of the State of Iowa, 1915), and in Harry Downer's History of Davenport and Scott County (Chicago: S. J. Clarke Publishing Company, 1910).
} 
Leader told of an unnamed German-American farmer's efforts to secure a military exemption for his son. According to the newspaper the farmer had accumulated great wealth after settling in Scott County and offered the net receipts of his farming operations to the Red Cross for the duration of the war on condition that his son be granted a military exemption. His offer was rejected and the newspaper noted that the young man was scheduled to leave for training camp on July 20th. ${ }^{3}$ The deletion of names by the newspaper suggests a less-than-honest editorial policy.

The report of a German-American who was declared disloyal and fined $\$ 100$ by the Scott County Council of National Defense, also was widely publicized. This man, Clauss Ruymann, had offered $\$ 100$ to anyone who could prove that he was disloyal. In response to Ruymann's challenge, local residents presented six signed affidavits to the Scott County Council of National Defense stating that Ruymann had refused to purchase Liberty Loans, and that he had announced his opposition to the United States' entry into the war. "Proven" disloyal, the council ordered Ruymann to pay his $\$ 100$ as a contribution to the Red Cross. ${ }^{4}$ Similar reports of disloyal acts by German-Americans appeared periodically in Davenport newspapers during the war. Exposure in the media of alleged disloyal acts of a few GermanAmericans tended to increase paranoia in the general public. As suspicions grew out of proportion, many German-Americans were suspected of disloyalty because of minor actions, or simply because they were of German descent.

Most reports of suspected disloyalty by German-Americans reported to the Scott County Council of National Defense were anonymous. The council's stated purpose was vague-"to divide equally the cost and the responsibility of the war, requiring every man to pay or serve, not according to this willingness, but according to his ability." of disloyal German-Americans by making investigations. If the

${ }^{3}$ Davenport Democrat and Leader, 19 July 1918.

- Davenport The Daily Times, 3 July 1918.

${ }^{5}$ Correspondence and Papers of the Scott County Council of National Defense, 1918, Davenport Public Museum, Davenport, Iowa. 
charges of disloyalty were found to be true, then the council would attempt to correct them. Although the Scott County Council of National Defense was part of a national organization that was under the direction of the federal government, its legal authority to investigate and punish disloyalty was never clearly established.

Investigations were frequently undemocratic. Accusations signed with such pseudonyms as "a party who knows," "no slacker," or "American friend" suggest an irrational hysteria. If the council believed that a report warranted further attention, it was turned over to the local branch of the American Protective League, a body that had assumed responsibility for investigating people suspected of disloyalty in Scott County. If the American Protective League discovered evidence of disloyalty, the accused person was called before the Council of National Defense where he gave testimony along with various witnesses. Persons found guilty, were "fined," advised to end all disloyal activities, and usually ordered to join and participate in a patriotic organization. ${ }^{6}$

The investigations and hearings conducted by the council and the league never dealt with major acts of sedition, but were restricted to "petty" violations. In the majority of cases, the accused was found to be not guilty. Often adequate evidence to warrant a hearing could not be found. However, if a hearing was held, those who testified often gave contradictory evidence. The investigations and hearings were most effective in creating an atmosphere of fear, and this in turn forced accused persons and other German-Americans to strongly demonstrate support for America's war effort.

A large number of the investigations concerned alleged statements of disloyalty. One message sent to the council accused a woman of always acting pleased at any good news for Germany, and speaking of "darned Yankees" and "darned Americans." She was also accused of holding up a small American flag and laughing at it. Investigators later learned that the flag incident reflected only an off-hand remark by the woman, and the investigation was dropped. ${ }^{7}$ Occasionally accusations back-

${ }^{\circ} \mathrm{Ibid}$.

${ }^{7}$ Ibid. 
fired, as in the case of a report that a German-American man had remarked that a display of patriotic posters and flags made him sick. Investigators discovered that the two men who had reported the incident told differing accounts and the loyalty of the two accusers was questioned by the council. ${ }^{8}$

Suspicions of German-Americans were often based on flimsy, if not silly, evidence. A German alien working for the Davenport Locomotive Works was accused of commenting that he knew the Kaiser well, and that he was a fine and handsome soldier. The man was also accused of never smiling or applauding while attending a patriotic speech. An investigation was held, and the man was called before the council for a hearing. During the hearing the man declared that he had only seen the Kaiser from the distance, and he had not intended his statement to be taken seriously. The council also questioned his immigration, his naturalization papers, and his work permit, and even his choice of friends. After the District United States Marshal verified all the man's statements, the case was dropped. ${ }^{9}$

In a few incidents of suspected disloyalty, angry citizens took matters into their own hands. In a Rock Island tractor factory, workers forced a fellow employee to kneel and kiss an American flag after he allegedly charged that President Wilson was a coward and that Germany was a better country than America. The man was believed to be a native of Germany, and because of his statements, he was suspended indefinitely from his job. ${ }^{10}$

A few German-Americans had their homes and business establishments painted yellow or were forced to kiss a flag by a group of angry citizens, but the number of such cases was far less than the number of disloyalty cases handled by the Council of National Defense. Interviews with Davenport residents in 1974 revealed that a few incidents of mob action were remembered-and apparently they were not treated as serious matters. The fact that German-Americans were often reported to the

${ }^{8}$ Ibid.

${ }^{9}$ Ibid.

${ }^{10}$ Davenport Democrat and Leader, 2 December 1917. 
Council of National Defense, however, was viewed with great concern by the interviewees. ${ }^{11}$

German aliens were regarded with greater suspicion, and were subjected to more stringent measures to ensure their loyalty, than were other German-Americans. The small number of German aliens living in Scott County-only 250 in 1918-were feared as a source of trouble. Only four days after the United States entered the war, United States Marshal Nicholas Reed issued a terse warning to Scott County German aliens: "Obey the law: Keep your mouth shut," in order to avoid trouble. ${ }^{12}$

As a security precaution, the federal government required all aliens to register and be placed under various restrictions. During registration, these aliens were required to present a photograph of themselves and be fingerprinted. ${ }^{13}$ All who failed to register were threatened with imprisonment for the duration of the war, and the public was requested to inform authorities of any German aliens whom they knew had not registered. Enemy aliens also were not allowed to own any weapons: shortly after war was declared aliens were ordered to turn in all revolvers and other weapons to the Davenport Chief of Police. Again, authorities threatened imprisonment to those who failed to comply. ${ }^{14}$

Perhaps the most important restriction in Scott County concerned the Rock Island Arsenal. Enemy aliens were required to obtain a permit to travel within one-half mile of the Arsenal, which manufactured arms and munitions for the war. If a review of an enemy alien's record revealed no indications of disloyalty, the United States Marshal would grant him a permit. A number of unnaturalized Germans received their permits and even worked in the Arsenal, but their fellow workers were urged to keep close watch on them. ${ }^{15}$ Since the bridge linking

\footnotetext{
${ }^{11}$ Interviews conducted by the author with twelve members of the GermanAmerican community of Davenport, Iowa, February and March, 1974. Due to the requests of the interviewees, names have been withheld.

${ }^{12}$ Davenport The Daily Times, 11 April 1917.

${ }^{13}$ Ibid., 21 January 1918.

${ }^{14}$ Davenport Democrat and Leader, 28 April 1918.

${ }^{15}$ Interviews with members of the German-American community of Davenport, Iowa, February and March, 1974.
} 
Davenport and Rock Island passed within one-half mile of the Arsenal, any enemy alien wishing to travel on it had to receive a permit. ${ }^{16}$ Without the permit an enemy alien would have great difficulty traveling about the Davenport-Rock Island area.

Even if enemy aliens registered and obeyed all laws, suspicion often remained. One young man in Scott County was under the impression that he was a naturalized citizen. The war security efforts uncovered the fact that his father had never completed his naturalization papers and therefore both he and his father were declared enemy aliens. Upon learning this, the young man took out naturalization papers, received his travel permit, and obtained a job with a contractor working on a United States Housing Project in Davenport. Despite all this, the superintendent and principal of the Davenport High School strongly questioned his loyalty. In a letter to the Chairman of the Council of National Defense, the two school officials severely criticized the employment of an enemy alien on the housing project, and said that their students would not assist in the project as long as he continued to work on it. ${ }^{17}$ Despite the fact that the man had done nothing to indicate that he was disloyal, he remained an object of distrust.

Just as the Council of National Defense had handled the majority of the cases of suspected disloyalty, it also took the lead in efforts to "Americanize" Scott County German-Americans. Americanization really meant that German-Americans were required to break all ties with Germany. In Scott County, Americanization centered around eliminating the use of the German language. German was used frequently in business establishments, churches, schools, and private homes in the county. The council believed that eliminating the use of German would make German-Americans more "American" and better ensure their loyalty. The drive to end the use of the German language in Scott County obtained legal status in Iowa Governor William Harding's May, 1918 language proclamation. In his proclamation Harding declared that only English

${ }^{16}$ Davenport Democrat and Leader, 19 June 1918.

${ }^{17}$ Correspondence and Papers of the Scott County Council of National Defense. 
would be used in public places throughout the state, and thus the council only enforced the governor's proclamation.

In one instance the council ordered the Davenport GermanAmerican Pioneer Association to end immediately the use of German in the Association's meetings. The Association was also advised that if the use of German continued, suspicions of the group's loyalty would naturally escalate. ${ }^{18}$ The directors of the Davenport Symphony also received a message from the council warning them to end the use of German during rehearsals. ${ }^{19}$

The council also attempted to end the use of the German language in telephone conversations in Scott County. Authorities launched one investigation because of a message that stated: "The Dutch still flys on 1913 Line, also the 1975 Line." Council officials asked local telephone operators to listen periodically to conversations on these lines and report any conversations overheard in German. When the council received no such reports, the case was dropped..$^{20}$ In another case a chairman of the council, Sam T. White, found four rural Le Claire women guilty of speaking German over the telephone. The women were fined and ordered to join the Le Claire Community Council of National Defense and to attend its meetings regularly. ${ }^{21}$

In an effort to curb the use of the German language in Scott County, the instruction of German in schools was eliminated. Here the Davenport School Board took the lead for loyalty. German was being taught at all levels in the Davenport public schools, and according to a survey taken in November, 1917, eighty percent of the children in the public schools were studying German. ${ }^{22}$ German language instruction was also prominent

\footnotetext{
${ }^{18}$ Correspondence and Papers of the Scott County Council of National Defense.

${ }^{19}$ Charles Ficke, Memories of Fourscore Years (Davenport: Graphic Services Incorporated, 1930).

${ }^{20}$ Correspondence and Papers of the Scott County Council of National Defense.

${ }^{21}$ Davenport Democrat and Leader, 14 June 1916.

${ }^{22}$ Davenport Democrat and Leader, 21 November 1917.
} 
in Davenport's private and parochial schools. Before the war, several of these schools taught one-half of each school day in German. After war was declared, however, many parents applied pressure to have German eliminated from the schools. The Board of Education responded to these pressures, and in May, 1918, it voted unanimously to eliminate German from all grades in the public schools. The Board gave as reasons for its decision the declining popularity of German and the general trend of its elimination from schools throughout the state. ${ }^{23}$ The private and parochial schools in the city soon followed the lead of the public schools, and shortly no Davenport students received instruction in the German language. ${ }^{24}$

The use of German declined sharply in Scott County. Instruction in German was not reinstated in the public schools until 1930, and it was never restored in the elementary grades. In some private and parochial schools, such as St. Joseph Catholic School in Davenport, the instruction of German never returned. Many German-Americans were bitter over the elimination of the language in the schools and felt that an important part of education in Davenport was lost. One woman described the action as, "the most narrow-minded thing I've ever heard of in my life." Many older German-Americans continued to speak German in their homes, but most of the younger people did not continue to use the language. ${ }^{25}$

In order to further Americanize the German-Americans in Scott County, local authorities eliminated books considered to be pro-German. In March, 1918, Grace Rose of the Davenport Public Library informed the Iowa Council of National Defense that all pro-German books had been removed from circulation. ${ }^{26}$ With the decision to end the teaching of German in the schools, the attack upon German books degenerated into violence. Only one day after the Board of Education's decision to ban German instruction, the students of Davenport High

${ }^{23}$ Ibid., 7 May 1918.

${ }^{24}$ Interviews with members of the German-American community of Davenport, Iowa, February and March, 1974.

${ }^{25}$ Ibid.

${ }^{26}$ Davenport Democrat and Leader, 11 March 1918. 


\section{The Annals of Iowa}

School took all German books out of the school and burned them in a public bonfire. Over 500 books were consumed in flames, including textbooks for the instruction of German, books containing pictures of the Kaiser, and maps of Germany. The majority of students greeted the book-burning with cheers, and regarded the event as a celebration. ${ }^{27}$ Similar book burnings occurred in public schools throughout the city.

The anti-German sentiment and Americanization campaign did effectively reduce the influence of German-Americans in Scott County. Not only did the use of the German language decline, but several German-American organizations disbanded or changed their names. During the war, members of the German-American Pioneer Association changed the name of their group to the Old Settlers Association, ${ }^{28}$ and the German Savings Bank in Davenport became the American Commercial and Savings Bank. ${ }^{29}$ In a front page statement September 7, 1918, the Der Demokrat, a daily German language newspaper with a large circulation among German-Americans in Scott County, announced that it would cease publication. Declaring that it had always been loyal to the United States, the newspaper blamed an anti-German prejudice that had developed in the country for its demise.

German-American organizations that survived the war experienced a decline in membership. In the Turn-Geminde, for example, membership declined sharply during the war and never returned to pre-war levels. Although the emotions and events during World War I caused a sharp decline in the membership in German-American organizations and the use of the German language, they were not totally responsible for the Americanization of Scott County German-Americans. The passing of the older generation and the natural loosening of ties with Germany had begun as assimilation process long before 1917, and the war years simply speeded up this process.

German-Americans were placed in the uncompromising position of having to take extreme actions in order to prove their

${ }^{27}$ Davenport The Daily Times, 8 May 1918.

${ }^{28}$ Davenport The Daily Times, 13 August 1918.

${ }^{29}$ Davenport Democrat and Leader, 8 July 1918. 
loyalty to the United States. This was evident in the actions of Henry Vollmer, one of the strongest pro-German spokesmen in Scott County before the United States' entry into the war. Vollmer assumed that his earlier stand would necessitate a strong pro-American position in order to eliminate doubts about his loyalty. Shortly after war was declared, Vollmer made a speech in which he asserted that he had always been and always would be loyal to the United States. ${ }^{30}$ In a letter to the editors of the Davenport Democrat and Leader Vollmer stated that any person who supported Germany should be shot to death. ${ }^{31}$

Vollmer's strongest action came in early March, 1918, when he proposed the formation of a German-American Patriotic Society in Davenport. He claimed that the Society would help to combat ". . . frequent poisoned arrows winged by narrowminded bigotry and prejudice . . . and to reestablish feelings of trust and confidence among our fellow citizens ..." ${ }^{\prime 32}$ Despite opposition from some German-Americans in Scott County, the Society was organized in Davenport.

Another German descendant took action similar to Vollmer's. Clauss Ruymann, who had been found to be disloyal and fined $\$ 100$ by the Council of National Defense, gave patriotic speeches to various German-American groups, throughout Scott County. In a speech at Blue Grass, Ruymann proclaimed, "We must be 100 percent American or we are traitors." ${ }^{33}$

The majority of those Davenport residents interviewed in 1974 also felt that the suspicions and actions of non-German residents of the county caused German-Americans to act in a manner that would prove their loyalty. One man was convinced that the main reason his father joined the army was to prove his loyalty. Several people expressed that German-Americans were very careful to act in no way that could be interpreted as disloyal, and conversely to take positive actions to prove their loyalty. The majority also felt that the suspicious feelings towards the German-Americans were very strong, and

${ }^{30}$ Davenport Democrat and Leader, 12 April 1917.

${ }^{31}$ Ibid., 11 January 1918.

${ }^{32}$ Davenport The Daily Times, 4 March 1918.

${ }^{33}$ Ibid., 27 August 1918. 


\section{The Annals of Iowa}

described them as "overblown" and "unjustified." Several persons confirmed that one German family left Davenport because of the anti-German feelings there, and one man stated that while at college he had seriously considered never returning to Davenport because of the bitter feelings that had developed during the war. ${ }^{34}$

Although the vast majority of German-Americans required no encouragement in order to support America's war effort, their fellow citizens often suspected their loyalty and attempted to guarantee it through coercion. These suspicious feelings and coercive actions were evident throughout the nation, and were especially strong in Scott County, Iowa. In attempting to ensure the loyalty of German-Americans in Scott County, the Council of National Defense was the most effective organization. Through its investigations and hearings, the Council created an atmosphere of fear among German-Americans that forced them to strongly support America in order to prove their loyalty. Americanization in Scott County centered around the elimination of the German language, and the council was joined in these efforts by the Davenport School Board. German aliens living in the county were extremely distrusted, and were placed under various restrictions handed down to local authorities from the federal government. The greatest effect of this suspicion and coercion was to pressure German-Americans to more strongly support the United States, and also to increase the assimilation process among German-Americans in Scott County.

${ }^{34}$ Interviews with members of the German-American community of Davenport, Iowa, February and March, 1974. 
Copyright of Annals of Iowa is the property of State of Iowa, by \& through the State Historical Society of Iowa and its content may not be copied or emailed to multiple sites or posted to a listserv without the copyright holder's express written permission. However, users may print, download, or email articles for individual use. 